\title{
On Heterodox Economics
}

\author{
B. Pradeep Kumar \\ Assistant Professor of Economics, Govt. Arts \& Science College Ambalapuzha, Kerala, India \\ Research Supervisor, University of Kerala, Kerala, India \\ (D) https://orcid.org/0000-0003-4232-9640
}

\section{OPEN ACCESS}

Manuscript ID:

ASH-2020-08023433

Volume: 8

Issue: 2

Month: October

Year: 2020

P-ISSN: 2321-788X

E-ISSN: 2582-0397

Received: 21.08.2020

Accepted: 24.09.2020

Published: 01.10.2020

Citation:

Pradeep Kumar, B. "On Heterodox Economics." Shanlax International

Journal of Arts, Science and Humanities, vol. 8, no. 2, 2020, pp. 65-69.

DOI:

https://doi.org/10.34293/ sijash.v8i2.3433

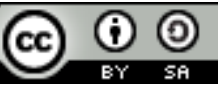

This work is licensed under a Creative Commons Attribution-ShareAlike 4.0 International License

\section{Abstract}

In the literature of Economics itself, branches have evolved thanks to different positions held by economists on different economic issues, and most importantly, on the efficacy and desirability of economic policies to address such economic issues. The so-called Classical and Keynesian poles apart positions have stood as the firm foundation for the germination of a couple of developments in economics. But, it may be reiterated that these positions have been premised upon several assumptions which often go diametrically opposite to real-world circumstances. The growing concern of the disconnect of the mainstream economics from the conditions of the real world has made a vacuum. The attention that heterodox economics has been receiving should be regarded as a response to this fill this vacuum. Google searching deliberations on the Covid-19 pandemic would find economics being discussed elsewhere and everywhere as if the economics of the Virus matters a lot rather than its biological side. Heterodox economics has grown to occupy an important place in modern economic thinking, and in the years to come, in the field of teaching as well, the elements discussed in heterodox economic will have an indisputable place. In the field of policy making, too, the principles of heterodox have been used. Nevertheless, mainstream economics does not seem to have been shaken by the claims of heterodox economics. For economics to continue as rigorous social science, much celebrated neo-classical tools and its ideas are still more important.

Keywords: Neo-Classical Economics, Keynesian economics, Margin concepts, Mainstream economics, Phillips Curve, Rationality assumption, Economic policy, Orthodox Economics, Marxian Economics and Behavioral Economics

\section{Introduction}

Economics as social science, in its evolution, since 1776 with the publication of the master piece 'Wealth of Nations' by its designated father, Adam Smith, has been experimenting with numerous developments, leading to the evolvement of several branches, often mixing up with contemporary social and purely science branches. In the literature of Economics itself, branches have evolved thanks to different positions which economists have held on different economic issues, and most importantly, on the efficacy and desirability of economic policies to address such economic issues. The so-called Classical and Keynesian poles apart positions have stood as the firm foundation for the germination of a couple of developments in economics. But, it may be reiterated that these positions have been premised upon several assumptions which often go diametrically opposite to real-world circumstances. Nevertheless, molders of such theoretical positions have always held that building up of such premises has become indispensable for science like economics whose interactions underlie unpredictable human behavior. The growing concern of the disconnect of the mainstream economics that has been enriched by the contributions of a galaxy of economics belonging mainly to Classical and Neo-Classical schools, from the conditions of the real world has made a vacuum. The attention that heterodox economics has been receiving should be regarded as a response to this fill this vacuum (Goodwin, 2008). This paper intends to discuss certain pertinent questions that arise in considering heterodox economics as a point of debate: such questions involve: what is all about heterodox economics? Is heterodox economics non-orthodox 
economics? Was Keynes the first heterodox economist? Heterodox: Does it need to be completely different from Mainstream Economics?

\section{What is all About Heterodox Economics?}

Before dwelling into the way heterodox economic may be defined, it is imperative to look into the so-called mainstream economics. Mainstream economics consists of existing theories of economics and interpretations there of (Mearman, 2011). It ranges from the time of Adam Smith to the Abhijith Sen, whose works have acclaimed wide attention in recent times owing to its practicability. Although modern economists like Abhijith Sen find their routes in rigid economic theories and principles, it is commendable to note that they have integrated themselves to the real-world conditions, not denying altogether the theoretical assertions their predecessors have made of the science of economics. The social lab approach of the recent Nobel laureates' couples stands outstanding and encouraging for new comers in the field of economics (Rajghatta, 2019).

Mainstream economics, it is often opined, has deviated itself away from ground economic and social realities. Economic models and theories evolved on the premise of rational assumptions do not hold any validity when tested against ground economic problems (Simon, 1959). Questions as to why some economies do not grow, even in the aftermath of the implementation of many economic policies apparently at the behest of the interest of the so-called messiah of economic policies like IMF, sounds very belligerent. Similarly, apprehensions arise when some segments of the population lag behind in advancing their economic prospects and expectations despite having been endowed with necessary supports that too when their peer groups move ahead, reaping all benefits of what the new regimes have showered on them. These contradictions raise the eyebrows of many when confronted with questions about the practical suitability of economic theories of principles wrapped in unrealistic and irrational presumptions. In this context, it is imperative to consider heterodox economics as an alternative to mainstream economics that often fails in accommodating real-world conditions. Looking through this lens, it is highly probable that heterodox economics put forward ideas and arguments that often lie outside the territories of mainstream economics.

Man being a social animal and whose interactions rely on many socio-cultural and moral variables, how so ever unyielding they are for quantitative capturing, it is indispensable that his economic interactions can hardly be disconnected from his engagement with the socio-cultural and institutional aspects in which he is present and interacts. Therefore, heterodox economics attempts to look into power dynamics and historical context in which economic problems crop up (Davis, 2007). To unearth the concealed aspects of such issues, heterodox economics strives to embed social, ethical, cultural, and historical factors that might have contributed to the emergence of the economic problem under consideration (Lawson, 2006). Viewing through this corner, one would argue that heterodox economics is a multidisciplinary approach to deal with economic issues. Quite the opposite to this, economics, more precisely mainstream economics, does not have to deal much with other associated realms of subjects and often discusses an economic issue in complete isolation of other related subjects that appear to have caused the emergence of the economic issue. On the other hand, mainstream economics is much more technical and perceived to be more and unnecessarily marketbased. In short, mainstream economics contradicts real-world circumstances while heterodox economics befriends and attempts to connect with the real world. With the importance that the heterodox economy has been gaining in recent times, although slowly, mainstream economics has been forced directly or indirectly to accommodate more practical social, economic, cultural and historical contexts while discussing certain newer problems. In its attempt to look for flexible models that come closer to the real-world situations, it has helped to shift the mainstream economics towards a more integrated approach. At this juncture, it may be pointed out that the importance attached to Behavioral economics in recent times in academic and research institutions pursuing economics science stands testimony to the space that this economics has gained in recent times.

To put in a nutshell, heterodox economics could well be regarded as a potpourri of schools in 
economics like behavioral economics, experimental economics, and feminist economics, and so on (Vernengo, 2011). In a sense, all these puts together stands against the mainstream school in economics. All economic theories in a way try to discuss the allocation of resources while in heterodox economics the distribution surplus occupied central issues apart from the traditional issues in economics (Vernengo, 2011). Simply speaking, heterodox economics can be defined as the study and analysis of economic principles that lie outside the mainstream or orthodox schools of economic thoughts. Defining in this way, heterodox economics may mean to include Marxian economics and Post-Keynesian economics (Halton, 2019). To comprehend the meaning and scope of heterodox economics, a set of series of heterodox principles may be helpful. The first is that in heterodox economics, the methodology that is how we approach economic issues seems important. Heterodox economics argue that human actors that appear in the realm of economics are social beings rather than as rational as posited by the orthodoxmainstream economics. Economic systems are unpredictable and therefore equilibrium needs to be revisited with suspicion. Individual and aggregate approaches can hardly be studied in isolation. That is in a way, micro-macro distinction may seem to be not practical. Heterodox economics also advances the view that power, mainly political power, is an important determinant of the outcome of the economic policies. These points, it is hoped, may sum up the crux of heterodox economics.

\section{Is Heterodox Economics Non-Orthodox Economics?}

Economics, today as we teach and study, remains largely unrepresentative of realities. This has made economics too abstract, unrealistic, and irrelevant, at least in some typical contexts. Many economists point out that the economics of today pays inadequate attention to the empirical evidence ${ }^{1}$ and historical backgrounds. The principal question that rises now is: is heterodox non-orthodox or not? It appears to defy the core of heterodox economics if one is to venture into defining heterodox as non-orthodox. To

1 In recent times, empirical research has started filling this void to a greater extent. A number of a research thesis that comes of Universities seem to have been flooded with empirical observations and analytical tools. say that heterodox is non-orthodox economics, one has a priori define the meaning of being 'orthodox,' which given the present wide strands of economic disciplines, seems entirely elusive. Some would refer 'orthodox' economics to neo-classical writings, which flourished and dominated, and still dominating, the realm of economics from the time of Alfred Marshall. However, approximating neo-classic economics as 'orthodox' would further complicate the problem because other and recently developed strands in economics like behavioral economics and ecological economics do not have any neo-classical footings. In fact, these new strands in economics defy, in many ways, the rational arguments put forward by the neo-classical to fathom the underlying factors that work behind many economic principles. Therefore, it may be exemplified that mainstream economics does not limit itself to the body of neoclassical musings rather it covers a wide strata of economic theories starting from the time of Adam Smith or much before. Another version might tempt us to say that heterodox economics is an alternative approach to existing body of economics. If this is taken for granted, then it should be reckoned that in economic history, there have always been alternatives. For instance, Keynesian economics was an alternative to the then existing economics of that time propagated by the Classical economics. When the world driven by the classical ideas was hit by the Great Depression, Keynes suggested opposite to what Classical economists had been advocating. With Keynesian magic, countries engulfed in great economic crisis could come out of that, Keynesian economics ought to be distinguished as heterodox economics. Not only Keynes did provide an alternative, Marx was also proposing an alternative to capitalism. Reading into these, one may have to content with the fact that heterodox economics dates back to the origin of economics itself.

In substance, heterodox economics ought to be conceived as a silent but growing revolution in economics to bring science closer to the ground realities of humanity. Perhaps on account of this understanding that heterodox economics is enriched with ideas that pin together pieces of history, sociology, ethics, politics and anthropology to dwell into the untold facets of the so-called economic 
turbulence that the world has been confronting with. Economics as a science has evolved through debates and controversies surrounding economic ideas, theories, and policies. There have been moments of arguments and counter-arguments which have added literature upon literature to this science, and perhaps owing to this reason, economics has come to occupy an unchallenging space in the domain of sciences elsewhere in the world. The history of economic thought invariably illustrates the crux of such debates that have made dynamism in science. Even today, amidst the echoes of unprecedented nature that the Covid-19 has created, perhaps, the most important center of deliberation around the world is not the health effects of such virus but the economic consequences. Google searching those deliberations, one would find economics being discussed elsewhere and everywhere as if economics of the Virus matters a lot rather than its biological side.

\section{Was Keynes the First Heterodox Economist?}

A classical system, as attributed to the writings of Adam Smith, David Ricardo, Thomas Malthus, and John Stuart Mill, had no place for the governments engaging themselves in influencing economic variables of any sort, be it through fiscal policy or monetary policy via central banks. The socalled principle of invisible hand did rule out any kind of interventionist polices at the hands of the government. Further, the Classical system went to the extent of arguing that unnecessary government interventions would derail the economy rather than putting it back on the track (Li, 2002). The classical and their supporters put substantiate arguments in support of an economic system completely free of all kinds of interventionist policies of governments. But, the great depression of 1930s had made things topsy-turvy. Persistent overproduction led to a decline in production, investment, and employment opportunities. When the western economic giants like the USA were suffering multiple economic and financial shocks emanating out of the economic policies then followed, Keynes found an inevitable solution to the problem of overproduction and impressed upon them to implement interventionist policies that might fill the void in the market which the private sector had left attended. Keynesian ideas at that time became revolutionary and went diametrically against classical beliefs. In some sense, one would argue that Keynesian economics should be regarded as the pioneering heterodox economics. Keynesian interventionist policies, especially expansionist policies increasing aggregate demand in the economy, found interesting takers both in the academic and policy fields. The success of the interventionist policy was empirically tested and proved correct when A.W.Phillips came out with the famous 'Phillips Curve, showing the tradeoff between inflation rate and unemployment rate (Humphrey, 1985). That is, although these twin problems could not be simultaneously solved, one issue could be reduced at the expense of the other, which would give space for policies of nations to be operated.

Given the current developments in economic thoughts, one can hardly say that Keynesian economics continues to persist as heterodox economics. In fact, over the years, Keynesian economics has become integrated with mainstream economics, although many ideas that Keynesian economics raised in the aftermath of the Great Depression in 1930 remain afresh. It may be reiterated here that the recent financial slowdown that erupted in the US brought back the importance of Keynesian economics to the limelight.

\section{Heterodox: Does it need to be Completely Different from Mainstream Economics?}

Is heterodox economics different altogether from the so-called 'mainstream' economics? Should heterodox economics be approached quite distinctly from the 'orthodox' or 'mainstream' economics? To address this perplexing question, one many need to ponder the realm of mainstream economics, particularly its theoretical foundations, and come to a concrete conclusion regarding the scope and coverage of mainstream economics. Heterodox economics, albeit tends to be using different methodological approaches while dealing with economic issues that the mainstream economics takes for deliberations, does not necessarily have to be quite deviating from the mainstream on account of the firm reason that the exact pillar of the economics remains unaltered even if some arguments that the heterodox economics 
put forth goes diametrically against the orthodox economics. For instance, the fundamentals of macro and micro economic equilibrium that we usually come across in 'mainstream' economics, by and large, remains applicable to the heterodox as well. For instance, it is stated that for a macroeconomic equilibrium, technically we need to have equality between the aggregate demand (AD) and aggregate supply (AS) and for consumer equilibrium Px (Price of $\mathrm{X}$ must be equal to Marginal Utility of the commodity $\mathrm{X}(\mathrm{Px}=\mathrm{MUx})$ and further for a producer, Marginal Revenue (MR) of commodity ' $\mathrm{x}$ ' must equal to its Marginal Cost (MC). These technical tools and inferences remain almost unaltered in heterodox economics. Still, there could be an additional qualification to the same in terms of the real economic, social, and political circumstances. Heterodox economics may also raise opinions regarding the changes in the theoretical approaches towards these fundamental aspects of the equilibrium of both the consumer and the producer. The tools in economics have not changed much; still, the conventional tools developed by the neoclassical writers find useful takers in all branches of economics which have come up later. Further, it is interesting to note that heterodox economics also regards private investment, consumption, and government expenditures the main drivers of economic activity (Lee, 2017).

\section{Concluding Remarks}

From this discussion, it is obvious that heterodox economics, by questioning the rude scientific nature of the mainstream economics, has been attempting to bring in a real face to the entire theories and analysis in economics. Undoubtedly, heterodox economics has grown to occupy an important place in modern economic thinking. In the years to come, in the field of teaching as well, the elements discussed in heterodox economic will have an indisputable place. In the field of policy making, too, the principles of heterodox have been used. Nevertheless, mainstream economics does not seem to have been shaken by the claims of heterodox economics. For economics to continue as rigorous social science, much celebrated neo-classical tools and its ideas are still more important.

\section{References}

Davis, John B. "The Turn in Recent Economics and Return of Orthodoxy." Cambridge Journal of Economics, vol. 32, no. 3, 2008, pp. 349-366. Goodwin, Neva. "From Outer Circle to Center Stage: The Maturation of Heterodox Economics." Future Directions of Heterodox Economics, edited by John T. Harvey, and Robert F. Garnett, University of Michigan Press, 2008.

Halton, Clay. "Heterodox Economics." Investopedia, 2019.

Humphrey, Thomas M. "The Evolution and Policy Implications of Phillips Curve Analysis."

Economic Review, vol. 71, 1985, pp. 3-22.

Lawson, Tony. "The Nature of Heterodox Economics." Cambridge Journal of Economics, vol. 30, no. 4, 2006, pp. 483-505.

Lee, F.S., and Tae-Hee Jo. Microeconomic Theory: A Heterodox Approach, Routledge, 2018.

Li, Ku-Wai. "Capitalist Development and Economism in East Asia: The Rise of Hong Kong, Singapore, Taiwan and South Korea." Asia-Pacific Development Journal, vol. 9, no. 1, 2002, pp. 109-120.

Mearman, Andrew. "Who Do Heterodox Economists Think They Are?" The American Journal of Economics and Sociology, vol. 70, no. 2, 2011, pp. 480-510.

Rajghatta, C. "India's A+ in Economics: After Amartya, it's Abhijit." Times of India, 2019.

Simon, Herbert A. "Theories of Decision-Making in Economics and Behavioral Science." The American Economic Review, vol. 49, no. 3, 1959 , pp. 253-283.

Vernengo, Matias. "The Meaning of Heterodox Economics, and why it matters." Naked Keynesianism, 2011.

\section{Author Details}

Dr. B. Pradeep Kumar, Assistant Professor of Economics, Government Arts \& Science College Ambalapuzha, Kerala, India and Research Supervisor, University of Kerala, Kerala, India, Email ID: pradeepgck@gmail.com. 